\section{Effect on Production and Quality of Intensifying Triploid Watermelon Crops Using 'Temporary Trellises' and CPPU for Fruit Development}

\author{
Francisco Javier Núñez \\ Departamento de Producción y Desarrollo de ANECOOP S. Coop. \\ c/ Monforte no 1, Entlo, Valencia, 46010, Spain
}

\begin{abstract}
Maria Victoria Huitrón
Instituto Tecnológico de Torreón, Coahuila, México; and Plant Production in Mediterranean Crop Systems Research Group, Escuela Politécnica Superior, Universidad de Almería, Almería, 04120, Spain

Manuel Díaz, Fernando Diánez, and Francisco Camacho-Ferre ${ }^{1}$ Plant Production in Mediterranean Crop Systems Research Group, Escuela Politécnica Superior, Universidad de Almería, Almería, 04120, Spain
\end{abstract}

Additional index words. plant density, temporary trellis, triploid watermelon (Citrullus lanatus Thunb.), CPPU

\begin{abstract}
In Spain, the adoption of the triploide 'Queen of Hearts' (Citrullus lanatus Thunb.) watermelon cultivar has brought important changes in the production of seedless watermelon thanks to its magnificent acceptance by the market. The experiments on triploid watermelon presented here examined innovative production techniques that would guarantee the productivity and quality of this cultivar in plastic greenhouses and improve cost-effectiveness, serving growers. Crop intensification was tested under a "temporary trellis" management system, increasing plant density from $2500 \mathrm{plants} / \mathrm{ha}$ in the traditional or creeping crop system to $10,000 \mathrm{plants} / \mathrm{ha}$. The "temporary trellis" system was combined with fruit set through the localized application of a 150- to 200-mg. $\mathrm{L}^{-1}$ solution of 1-(2-chloro-4-pyridyl)-3-phenylurea (CPPU). The increase of grafted watermelon plant density to $1 \mathrm{plant} / \mathrm{m}^{2}$ gave rise to an increase in early harvest measured as the number of fruits per surface area compared with the traditional system with a density of $0.25 \mathrm{plant} / \mathrm{m}^{2}$. In addition, a process of temporary trellising facilitates choosing female flowers for applying CPPU. The ${ }^{\circ} \mathrm{Brix}$ and pulp firmness quality parameters did not show significant differences between "temporary trellised" and creeping crops.
\end{abstract}

Spain is one of the chief watermelonproducing countries in the world. With an area of 16,200 ha (28th position in world rating) and a production of $717,500 \mathrm{t}(12 \mathrm{th})$, it is the country with the greatest productive output per surface area, $44.29 \mathrm{t} \cdot \mathrm{ha}^{-1}$ (fourth) (FAOSTAT, 2007).

The region of Andalusia accounts for $44 \%$ of Spain's production area. Almeria stands out as the main province with $72 \%$ and $32 \%$ of the Andalusian Spanish area, respectively. Almeria produces 334,965 $\mathrm{t}$ on an area of 5060 ha for an average output of $66.2 \mathrm{t} \cdot \mathrm{ha}^{-1}$ (Huitrón, 2005; Junta de Andalucía, 20052006).

The commercial cultivation of watermelon in Almeria began in the 1960s. Since then, production techniques have improved continually. Almeria profitability depends on

Received for publication 4 June 2007. Accepted for publication 17 Sept. 2007.

${ }^{1}$ To whom reprint requests should be addressed; e-mailfcamacho@ual.es high productivity and earliness (Camacho and Fernández, 2000).

The market has evolved, demanding new types of watermelon that meet consumer needs. Triploid seedless cultivars have become widely used.

Despite important commercial advantages, triploid cultivars present special production related to their need for pollination by diploid cultivars because the triploid produce sterile pollen. This implicates the designing of plantations with diploid and triploid cultivars. These cultivars must also be easily identifiable (Camacho and Fernández, 2000) to prevent mixing seedless and seeded fruit at harvest. Other problems can arise during pollination if the time of flowering of both cultivars fails to coincide adequately (Camacho and Fernández, 1997) or if environmental conditions are not favorable for insect pollination (Miguel et al., 2001). There can be management problems as well associated with the use of both cultivars simultaneously, harvest, transportation, preparation, fertilization, and so on.
Production costs for triploid cultivars are also higher than for traditional diploid watermelons, mainly as a result of the higher cost of seed. Therefore, it is important to obtain greater yields so the crop will be more profitable to the farmer.

All these negative aspects of pollination triploid watermelon justify conducting various studies on the use plant regulators has on triploid watermelon fruit set. Such regulators as auxins on the plant and 1-(2-chloro-4pyridyl)-3-phenylurea (CPPU) on the flower replace diploid cultivars as pollinators, giving way to the production of exclusively seedless watermelon (Camacho and Fernández, 2000).

Another technique that could help increase watermelon yield is based on augmenting plant density. Seed costs would rise but can be compensated by an increase in output and, depending on market conditions, by higher profits per hectare (Ban et al., 2006). One way to increase yield is to establish the crop in an "entrained" system. This system can augment yield per surface area unit to a certain point after which, as a result of competition among plants, it declines (Duthie et al., 1999).

The use of "trellises" as a management system offers a series of agricultural advantages to conventional plantings but not without drawbacks. Selecting the number of branches to form the plant permits improved crop aeration, health, use of space, and capture of solar radiation. However, in the case of watermelon, as a result of the elevated weight of the fruit, which the stem cannot withstand. A watermelon of a certain size will break the stem and the fruit falls off the plant. If the plant were capable of holding up such weight, a change in the structural elements of plastic greenhouses would be necessary so that it could withstand 50 to $60 \mathrm{t} \cdot \mathrm{ha}^{-1}$. Bagging the fruit and tying the bags to the greenhouse trellis wires has been tried (Camacho and Fernández, 1997). In the present experiment, the trellis wires were cut once plant shoots had the desired number of developing fruit. The plant finished the rest of its cycle on the ground, a conventional way for growing watermelon.

The system used offers the following advantages:

1. Simple plastic house structures can be used because they do not have to withstand excessive weight.

2. It facilitates choosing female flowers, which develop better after CPPU application.

3. Applying CPPU to the flower is more comfortable and quicker for the worker because it is done standing up instead of stooping over.

4. The number of fruits that the plant develops at a given time is easily controlled helping predetermine fruit size for specific markets. Previous research found that with an increase in plant density, the number of fruits per surface area unit increased significantly, 
but their average weight decreased (Edelstein and Nelson, 2002).

Guaranteed fruit set is sought through the use of plant regulators. This prevents all the agricultural problems of pollination derived from the simultaneous use of two different cultivars and adverse climatic conditions. Productivity is also improved by not planting pollinating (diploid) watermelon, which decreases the quantity of the triploid product per unit of crop surface area and yields seeded fruit of lower economic value to the producer.

The objectives posed for the experiments were:

1. To evaluate the effect on production and quality of the triploid watermelon cultivar 'Queen of Hearts' under a "temporal trellised" production system as opposed to the traditional creeping system; and

2. To develop a production methodology based on the use of cytoquines as plant regulators for inducing the formation of triploid watermelon.

\section{Materials and Methods}

The experiments were carried out at the UAL-ANECOOP Foundation Experimental Farm located at Paraje de los Goterones in the municipal district of Almeria $\left(2^{\circ} 17^{\prime} \mathrm{W}\right.$ long. and $36^{\circ} 52^{\prime} \mathrm{N}$ lat.). The crop was grown in a multicovered plastic greenhouse of the "Raspa y Amagado" (covered skeleton structure) type, $5 \mathrm{~m}$ high along the top and $4.5 \mathrm{~m}$ high along the shoulder, lying in an east-west direction, with sand-covered soil and a total greenhouse surface area of 1800 $\mathrm{m}^{2}$. The plastic covering was 200 micra trithermal polyethylene film with a useful life of 3 years. Module ventilation was passive with lateral and zenithal windows protected by 50 mesh antithrip screens. Climatic control was achieved manually. The covering of the plastic house was limed with calcium carbonate on 10 May 2005, 92 days after transplant (DAT) in the first experiment and on 18 May 2006 (98 DAT) in the second one to avoid the elevated temperatures in the months of May and June. The triploid watermelon cultivar used was 'Queen of Hearts' grafted onto the Cucurbita maxima $\times$ Cucurbita moschata cultivar 'Strongtosa' interspecific hybrid. Transplant of grafted seedlings to the greenhouse occurred on 8 Feb. 2005 and 10 Feb. 2006, respectively, whereas early harvest was carried out on 4 May 2005 (86 DAT) and on 4 and 11 May 2006 (84 and 91 DAT, respectively).

Both harvests were obtained through applications of CPPU conducted during the final week of March and the first week of Apr. 2005 and 2006, respectively. Then the plant resprouted and fruit set again around the months of May through June for another harvest at the end of June (see Tables 1, 2, 3 , and 4).

Table 1. Dates of plant regulator application for the spring of 2005 test, days after transplant (DAT), concentration of the solution in water in ppm, and crop arrangement.

\begin{tabular}{lcccc}
\hline Date & DAT & Plant regulator & Concn $(\mathrm{ppm})$ & Crop arrangement \\
\hline 18 March 2005 & 38 & CPPU & 200 & Trellised/creeping \\
23 March 2005 & 43 & CPPU & 200 & Trellised/creeping \\
30 March 2005 & 50 & CPPU & 150 & Trellised/creeping \\
\hline
\end{tabular}

CPPU $=$ 1-(2-chloro-4-pyridyl)-3-phenylurea.

Table 2. Date of plant regulator application for resprouting in the spring of 2005 test, days after transplant (DAT), concentration of the solution in ppm, and crop arrangement.

\begin{tabular}{lrccc}
\hline Date & DAT & Plant regulator & Concn $(\mathrm{ppm})$ & Crop arrangement \\
\hline 11 May 2005 & 92 & CPPU & 100 & Creeping \\
21 May 2005 & 102 & CPPU & 100 & Creeping \\
\hline
\end{tabular}

CPPU $=$ 1-(2-chloro-4-pyridyl)-3-phenylurea.

Table 3. Date of plant regulator application in the spring of 2006 test, days after transplant (DAT), concentration of the solution in ppm, and crop arrangement.

\begin{tabular}{lccc}
\hline Date & DAT & Concn $(\mathrm{ppm})$ & Crop arrangement \\
\hline 20 March 2006 & 40 & 200 & Trellised/creeping \\
23 March 2006 & 43 & 200 & Trellised/creeping \\
28 March 2006 & 48 & 200 & Trellised/creeping \\
30 March 2006 & 50 & 200 & Trellised/creeping \\
3 Apr. 2006 & 53 & 150 & Trellised/creeping \\
6 Apr. 2006 & 56 & 150 & Trellised/creeping \\
\hline
\end{tabular}

Planting framework for the creeping crop was $4 \mathrm{~m}$ between crop rows and $1 \mathrm{~m}$ between plants (plant density of 0.25 plant $/ \mathrm{m}^{2}$ ). Framework for the trellised crop was $2 \mathrm{~m}$ between rows and $0.5 \mathrm{~m}$ between plants (plant density of 1 plant $/ \mathrm{m}^{2}$ ). Trellising began on 2 March 2005 (23 DAT) for the first experiment and on 4 March 2006 (23 DAT) for the second one. Four sprouts were selected per plant and the remainder, which were not trellised, were eliminated. Trellising was maintained for the first experiment until 29 March 2005 (27 d) and 27 March 2006 for the second one when the plants were let down and left on the ground.

Fruit development was induced through the use of the cytoquine authorized for kiwi in Spain, which is not in the MAPA CPPU database: 1-(2-chloro-4-pyridyl)-3-phenylurea (forchlorfenuron). The application of the solution was made with a manual nebulizer directly on the ovary of each flower. A volume of $0.5 \mathrm{~mL}$ of solution was applied to each ovary.

The design was completely randomized blocks following a linear model with four blocks and two treatments corresponding to both experimental management systems. Elemental plot dimensions were $15 \times 6.80 \mathrm{~m}$.

For data collection, all the fruits harvested in each elemental plot were counted, and 10 fruits were selected at random from each plot. They were weighed to determine production parameters: early production $\left(\mathrm{kg} \cdot \mathrm{m}^{-2}\right)$ as well as yield components (average fruit weight in $\mathrm{kg}$, number of fruit $/ \mathrm{m}^{-2}$, number of fruit/ plant). Of these 10 fruits, three were randomly selected for an external quality analysis (longitudinal and transverse perimeters, coefficient of shape, size of pistil scar in millimeters) and for internal quality (pulp firmness as $\mathrm{kg} \cdot \mathrm{cm}^{-2}, \mathrm{pH}$, rind width in millimeters, ${ }^{\circ}$ Brix, pulp color).
Table 4. Date of plant regulator application for resprouting in the spring of 2005 test, days after transplant (DAT), concentration of the solution in ppm, and crop arrangement.

\begin{tabular}{lccc}
\hline Date & DAT & $\begin{array}{c}\text { Concn } \\
(\mathrm{ppm})\end{array}$ & $\begin{array}{c}\text { Crop } \\
\text { arrangement }\end{array}$ \\
\hline 22 May 2006 & 103 & 150 & Creeping \\
26 May 2006 & 107 & 150 & Creeping \\
31 May 2006 & 111 & 100 & Creeping \\
\hline
\end{tabular}

Data were statistically analyzed by analysis of variance analysis with a $95 \%$ confidence level followed by a multiple range test (least significant difference) to differentiate among averages.

Data were statistically analyzed by a variance analysis following the $y_{i j}=\mu+\alpha$. $+\beta_{j}+\varepsilon_{i j}$ model for a confidence level of $95 \%$.

The statistics package used was STATGRAPHICS Plus 4.0 for Windows (Manugistics, Rockville, MD).

\section{Results and Discussion}

The effect of the management systems used in the triploid watermelon on early production, accumulated total yield $\left(\mathrm{kg} \cdot \mathrm{m}^{-2}\right)$, and yield components (fruit $/ \mathrm{m}^{2}$ and fruit/ plant) are shown in Table 5.

Early harvest in watermelon crops was defined as the product obtained from the first or the first and second fruit cuttings, when there is no more than 1 week's difference between them. Early production is what was obtained at 92 DAT in 2005 and 83 and 90 DAT in 2006. After these harvests, watermelon proceeded to sprout again, forming new stems and producing another flowering. Fruit set again to produce another harvest at 142 DAT in the 2005 season and at 139 DAT in 2006. This harvest was called "resprouting."

In 2005 , differences in commercial production obtained by different crop systems 
were significant. The trellised crop surpassed the creeping crop by $2.42 \mathrm{~kg} \cdot \mathrm{m}^{-2}$. These results were not confirmed in the experiment carried out in the spring of 2006.

There were no significant differences in early production either year between treatments, although plant density $\left(0.25 \mathrm{plant} / \mathrm{m}^{2}\right)$ was higher in the "trellised" treatment than in the creeping treatment $\left(1\right.$ plant $\left./ \mathrm{m}^{2}\right)$. However, there were significant differences in both years in the number of commercial fruit per surface area in favor of the trellised crop for early as well as total production. As expected, there were differences in the number of commercial fruits per plant in favor of the creeping management system.

Resprouting accounted for between $12.5 \%$ and $16.5 \%$ of the commercial production. Resprouted fruit were developed by again applying CPPU when the trellised plant was already on the ground. Therefore, there was no difference between either experimental crop in the way that this application was made.

Results from research by Salvador (2006) on watermelon cultivar 'Solinda', with the same plant density, in "temporary trellising" (1 plant $\left./ \mathrm{m}^{2}\right)$ as well as in creeping crops $\left(0.25 \mathrm{plant} / \mathrm{m}^{2}\right)$, did not show significant differences between production systems either in total or early production.

Average production from our experiments was comparable to commercial production in the area using insect pollination in the same cultivar and under similar crop conditions as for these experiments. Commercial yields averages $\approx 6 \mathrm{~kg} \cdot \mathrm{m}^{-2}$ on two-thirds of the surface area sowed with triploid watermelon and one-third planted with diploid watermelon. (Junta de Andalucía, 2005-2006).

In our trial, there were significant differences in average fruit weight from the early harvest in favor of the creeping crop, but none in the resprouted harvest (Table 6). The shape coefficient showed no significant differences between treatments, although such differences did exist in the longitudinal perimeter of early harvested fruit in favor of the creeping system. Nevertheless, the fruit from 'Queen of Hearts' watermelon maintained the slightly ellipsoidal shape characteristic of this variety conforming to the

Table 5. Effect of the management system on commercial production $\left(\mathrm{kg} / \mathrm{m}^{2}\right)$ and production components (fruit $/ \mathrm{m}^{2}$, fruit/plant) for early as well as total production in triploid watermelon cultivar Queen of Hearts crops when using CPPU for fruit set.

\begin{tabular}{|c|c|c|c|c|c|c|}
\hline \multirow[b]{2}{*}{ Treatment } & \multicolumn{2}{|c|}{$\begin{array}{c}\text { Commercial } \\
\text { production }\left(\mathrm{kg} \cdot \mathrm{m}^{-2}\right)\end{array}$} & \multicolumn{2}{|c|}{$\begin{array}{c}\text { Commercial } \\
\text { fruit } / \mathrm{m}^{2}\end{array}$} & \multicolumn{2}{|c|}{$\begin{array}{c}\text { Commercial } \\
\text { fruit/plant }\end{array}$} \\
\hline & Early & Total & Early & Total & Early & Total \\
\hline \multicolumn{7}{|l|}{2005} \\
\hline Creeping & $6.05 \mathrm{a}$ & $8.30 \mathrm{~b}$ & $0.95 \mathrm{~b}$ & $1.45 \mathrm{~b}$ & $3.80 \mathrm{a}$ & $5.78 \mathrm{a}$ \\
\hline Trellised & $8.31 \mathrm{a}$ & $10.72 \mathrm{a}$ & $1.63 \mathrm{a}$ & $2.13 \mathrm{a}$ & $1.63 \mathrm{~b}$ & $2.13 \mathrm{~b}$ \\
\hline$P$ value & 0.084 & 0.042 & 0.023 & 0.012 & 0.032 & 0.009 \\
\hline Variable coefficient & 23 & 17 & 33 & 23 & 40 & 51 \\
\hline $\mathrm{SE}$ & 0.67 & 0.66 & 0.17 & 0.17 & 0.51 & 0.82 \\
\hline \multicolumn{7}{|l|}{2006} \\
\hline Creeping & $5.10 \mathrm{a}$ & $6.95 \mathrm{a}$ & $1.18 \mathrm{~b}$ & $3.03 \mathrm{~b}$ & $3.57 \mathrm{a}$ & $5.26 \mathrm{a}$ \\
\hline Trellised & $5.64 \mathrm{a}$ & $7.87 \mathrm{a}$ & $2.20 \mathrm{a}$ & $3.65 \mathrm{a}$ & $1.20 \mathrm{~b}$ & $1.69 \mathrm{~b}$ \\
\hline$P$ value & 0.461 & 0.052 & 0.005 & 0.019 & 0.000 & 0.000 \\
\hline Variable coefficient & 25 & 12 & 42 & 16 & 60 & 60 \\
\hline $\mathrm{SE}$ & 0.34 & 0.23 & 0.19 & 0.13 & 0.31 & 0.45 \\
\hline
\end{tabular}

Test for minimum significant differences. Least significant difference analysis. Numeric values followed by a letter denote statistical significance of $P<0.05$.

CPPU $=1$-(2-chloro-4-pyridyl)-3-phenylurea.
ANECOOP quality standard for Bouquet watermelon (ANECOOP, 2006).

Significant differences did not exist in soluble solids content or pulp firmness between treatments in the spring of 2006 (Table 7). In both experiments, soluble solids levels were superior to $9^{\circ}$ Brix, the criterion by the ANECOOP for "top of the line" watermelon.

Regarding rind thickness and pulp color, significant differences were obtained in the 2006 harvest in resprouted fruit with thinner rinds and higher intensity in pulp color for the creeping treatment than the trellised one. In 2005, no significant differences were obtained. In other experiments on watermelon cultivar 'Solinda' (Salvador, 2006), significant differences were obtained in quality parameters, pulp color, rind thickness, fruit acidity, and pulp firmness with improved 1.0 plants $/ \mathrm{m}^{2}$ in characteristics at 0.25 plants $/ \mathrm{m}^{2}$.

With regard to the Bouquet quality standard, rind thickness in both tests was lower than the $20 \mathrm{~mm}$, the maximum limit for that standard, whereas internal coloring characteristic of the variety was maintained.

In the 2006 experiment, significant differences were found in acid content in the cutting at 90 DAT. Slightly more acidic watermelon was obtained from the trellised crop, whereas no significant differences were found in the resprouting crop. As for the size of the pistil scar, significantly larger pistil closures were obtained in the creeping crop compared with the trellised one. These 2006 results were not consistent with those in 2005, which did not show significant differences, although the tendency was maintained toward higher average values in the size of pistil scars.

\section{Conclusions}

The increase in plant density to $1 \mathrm{plant} / \mathrm{m}^{2}$ through the "temporary trellis" system increased the number of commercial fruits per surface area unit despite the loss of productive potential of each plant being

Table 6. Effect of plant regulator application for fruit set in triploid watermelon cultivar Queen of Hearts on average fruit weight $(\mathrm{kg})$, longitudinal perimeter (cm), transverse perimeter $(\mathrm{cm})$, and relationship between longitudinal and transverse perimeter (LP/TP).

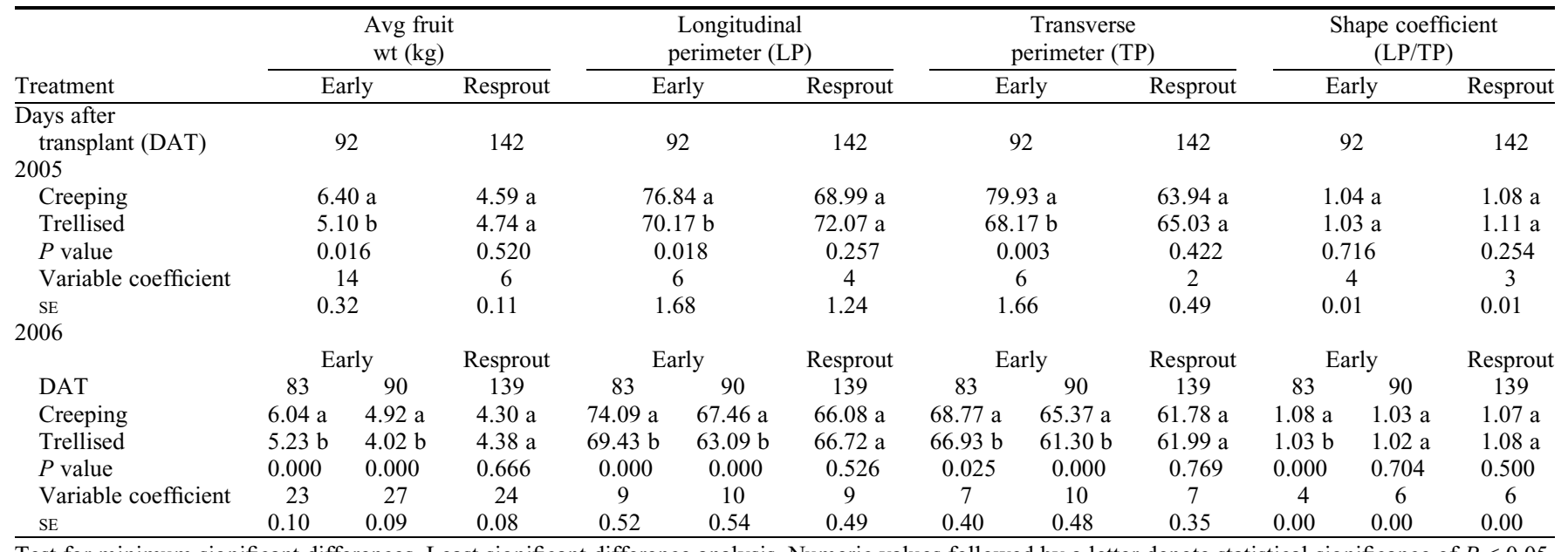

Test for minimum significant differences. Least significant difference analysis. Numeric values followed by a letter denote statistical significance of $P<0.05$. 
significantly reduced as a result of mutual competition as plant density increased. No advantage was obtained compared with the creeping crop with a four times lower plant density.

In the "temporary trellis" system, the average weight of watermelon cultivar 'Queen of Hearts' was significantly reduced compared with the sparser creeping crop. The slightly ellipsoidal shape characteristic of the variety was maintained.

The quality of watermelon cultivar 'Queen of Hearts' was unaffected by crop intensification through temporary trellising.

\section{Literature Cited}

ANECOOP. S. Coop. 2006. Sistema de calidad para la sandia Bouquet. Ver. 4.

Ban, D., S. Goreta, and J. Borosic. 2006. Plant spacing and cultivar affect melon growth and yield components. Scientia Hort. 109:238-243.

Camacho, F. and E.J. Fernández. 1997. El entutorado de la sandía diploide. Horticultura 125 : $13-16$

Camacho, F. and E.J. Fernández. 2000. El cultivo de la sandía apirena injertada, bajo invernadero, en el litoral mediterráneo español. Ed. Caja Rural de Almería.

Duthie, J.A., B.W. Roberts, J.V. Edelson, and J.W. Shrefler. 1999. Plant density-dependent variation in density, frequency, and size of watermelon fruits. Crop Sci. 39:412-417.

Edelstein, M. and H. Nerson. 2002. Genotype and plant density affect watermelon grown for seed consumption. HortScience 37:981-983.

FAOSTAT. 2007. FAOSTAT database. 5 Sept 2007. <http://faostat.fao.org/site/567/Desktop Default.aspx?PageID $=567>$.

Huitrón, M.V. 2005. Cuaje de sandía mediante el empleo de fitorreguladores. Influencia de cultivares y portainjertos sobre parámetros productivos y de calidad. Escuela Politécnica Superior, Universidad de Almería, PhD Diss.

Junta de Andalucía. 2005-2006. Memoria resumen de la producción total agraria de la provincia de Almería

Miguel, A., J.V. Maroto, and S. López-Galarza. 2001. Production of different triploid watermelon cultivars without pollinators. Acta Hort. 559:145-148

Salvador, M.T. 2006. Evaluación económica y productiva de dos sistemas de cultivo: entutorado y rastrero, en sandía mini triploide cv. solinda sin polinizador, utilizando citoquininas (CPPU) para la formación de frutos. Proyecto Fin de Carrera, Escuela Politécnica Superior, Universidad de Almería. 